\title{
Effects of Professional Skepticism, Competency and Workload Compression on the Ability to Detect Possible Fraud Among Government Auditors
}

\author{
Mochammad Solichin $^{1^{*}}$, Zuraidah Mohd-Sanusi ${ }^{2}$, Razana Juhaida Johari ${ }^{3}$ and Tri \\ Gunarsih $^{4}$ \\ ${ }^{1}$ Faculty of Business and Humanities, \\ Universitas Teknologi Yogyakarta, Indonesia \\ ${ }^{2}$ Accounting Research Institute, \\ Universiti Teknologi MARA, Selangor, Malaysia. \\ ${ }^{3}$ Faculty of Accountancy, Universiti Teknologi MARA, Selangor, Malaysia \\ ${ }^{4}$ Faculty of Business and Humanities, \\ Universitas Teknologi Yogyakarta, Indonesia
}

\begin{abstract}
The purpose of this study was to investigate the impact of professional scepticism, competence, and workload compression on an auditor's ability to detect potential fraud. This sample consisted of 149 government auditors from the Indonesian Local Government Inspectorate. Data was gathered through the use of a questionnaire and analysed using the Partial Least Squares Structural Equation Modeling. The findings revealed that internal attribution (professional scepticism and competency) have a significant impact on an auditor's ability to detect the possibility of fraud. Workload compression as an external attribution, did not have a meaningful influence on an auditor's ability to detect probable fraud. Workload reduction was also found to be ineffective in moderating the relationship between internal attribution and an auditor's ability to detect probable fraud. The findings can guide local governments in developing policies aimed at enhancing the role of government auditors in detecting fraud.
\end{abstract}

Keywords: government auditors, professional skepticism, attribution, workload compression

\section{ARTICLE INFO}

\section{Article History:}

Received: 28 May 2021

Accepted: 25 August 2021

Published: 1 December 2021

* Corresponding author: Mochammad Solichin. Email: massolichin72@gmail.com 


\section{INTRODUCTION}

Regional financial reforms implemented in Indonesia aim not only to realize good governance but also to offer a model for financial management that is oriented towards the welfare of the community. In accordance with its function as a public sector organization, the government must improve services for the community. However, in its implementation, irregularities were still found that led to fraudulent acts. Fraud causes losses to regional finances which hinder the achievement of local government goals towards good governance. Fraud is a deviant act that is intentionally carried out in the form of omitting or adding a certain amount so that there is a misstatement in the financial statements (Aji, 2014).

Fraud is often found in manipulating financial documents and reports, misuse of assets, mark-ups in the financing, and loss of state revenues in the government sector. The factors causing fraud usually start from the opportunity to commit irregularities (Hartan \& Waluyo, 2016). A survey conducted by Transparency International Indonesia for 2019 placed Indonesia in the 85th rank of 180 countries with a corruption perception index score of 40. This data shows that Indonesia still has a reasonably serious corruption problem.

The number of cases of fraud that has occurred, especially in local governments in recent years, is an indication of the failure of supervision in the management of regional finances by the internal supervisory apparatus, in this case, the Government Internal Supervisory Apparatus (called APIP) located at the Inspectorate office. This is reinforced by the many cases of audit findings by external auditors (called BPK) that lead to fraudulent acts without being noticed by government auditors. Based on the examination results in the first semester of 2019, the BPK revealed 9,116 findings with a value of IDR 10.35 trillion (BPK, 2019). These findings include internal control weaknesses, problems of non-compliance with statutory provisions, and problems of inefficiency, and ineffectiveness. These problems can result in losses, potential losses, and potential shortfalls of revenue for the State.

According to Coram et al. (2006) and Gamar and Djumhuri (2015), organizations with an effective internal audit function can better detect and reduce the possibility of fraud. Meanwhile, Moroney (2006) stated that a 
qualified internal auditor will detect fraud and quickly inform management. This raises questions about the role of APIP as a government auditor in preventing and detecting possible fraudulent acts in government institutions. For this reason, it is necessary to examine in more depth the factors that can influence government auditors in detecting the possibility of fraud as part of an effort to improve the supervisory function performed by government auditors.

Many factors can influence the assessment of government auditors in detecting the possibility of fraud. These factors can be examined from two perspectives. This point of view includes both internal factors (personal characteristics) and external factors (community environment, professional body, or workplace) that influence individual judgment (Einhorn \& Hogarth, 1981). The Attribution Theory (AT) states that a person's behavior is determined by a combination of internal and external forces (Heider, 1958). Internal strength, in this case, is in the form of professional skepticism and competency, while the variable workload compression becomes an external force that affects an auditor's judgment in detecting the possibility of fraud.

Previous research results have found that low professional skepticism is one of the causes of auditors' failure to detect fraud (Beasley et al., 2013). Most of the audit failure cases found were caused by a low level of professional skepticism. The Professional Standards for Public Accountants (SPAP) in Indonesia explains that professional skepticism is an attitude that always questions and critically implements audit evidence evaluation products (IAPI, 2012). By having a high professional skepticism attitude encourages auditors to always want to find more information. Tuanakota (2010) stated that low professional skepticism will reduce an auditor's sensitivity to fraud and signs of danger that indicate errors and fraud.

In addition to professional skepticism, auditors must also have the competence (SPKN, 2012). It is hoped that auditors involved in the assessment of fraud detection are expected to have the competence needed to assess the possibility of the risk of fraud and to be strengthened by an adequate level of assessment to ensure that risks are correctly handled (Baran \& Kłos, 2014). The competence of government auditors in making good assessments illustrates their innate abilities to assist them in evaluating the auditee's risk factors. Previous studies have found that sometimes 
government auditors are not competent enough to carry out the tasks required by their positions (Simwayi \& Wang, 2011). Insufficient competence, prevents government auditors from conducting a comprehensive assessment and ultimately run the risk of failure to detect fraud.

Apart from internal factors such as professional skepticism and competence, the ability of the government auditors to detect the possibility of fraud can be influenced by external factors such as an auditor's workload. These external factors can change the way a person carries out a given task with the level of knowledge, effort, and motivation dedicated to the task (Mala \& Chand, 2015). According to Nasution and Fitriany (2012), workload compression is the amount of work a person must do. Workload compression that is too heavy that exceeds physical ability can decrease work quality (Lopez \& Peters, 2012). Workloads that are too heavy can also cause fatigue, thereby reducing the ability of auditors to spot fraud. Schultz (2006) stated that a high workload will cause stress and reduce performance.

In line with the AT, which states that internal and external attributions influence a person's performance or ability, this study aimed to empirically test internal attributions (professional skepticism and competency) and external attributions (workload) that affect the assessment of local government auditors in detecting possible fraud.

\section{LITERATURE REVIEW AND HYPOTHESES DEVELOPMENT}

\section{Attribution Theory}

The AT was used as a framework for understanding how individuals interpret their behavior and the behavior of others. The AT emphasizes how individuals interpret events and how they are related to their thinking and behavior (Heider, 1958). This theory explains that when individuals observe a person's behavior, the individual tries to determine whether the behavior is caused internally or externally (Robbins \& Judge, 2008). Internally generated behavior is under a person's control, which is not affected by anything else. Meanwhile, externally caused behavior is considered a result of conditions outside the individual, which is considered a situation that forces individuals to behave in a particular way. 
This study adopted the AT to explain the effect of professional skepticism and competency (internal attributions) and workload (external attributions) on the ability of government auditors to detect possible fraud. The theory explains that the level of performance expected to be achieved in the future, in a particular task, depends on specific causes associated with previous success or failure in the same task (Jaffar et al., 2008). This theory is appropriate for this study because of the need to assess the causal attributions of auditors' performance, namely the ability to detect possible fraud. With this theory, the ability to detect fraud that is expected in the future is associated with internal attributions and external attributions. Attribution relates to a person's judgment and describes how an auditor behaves. The auditor's ability to detect fraud is primarily determined by internal and external attributions, where the factors that determine the ability come from within the auditor (Kartikarini \& Sugiarto, 2016).

\section{Professional Skepticism and The Auditor Ability to Detect Possible Fraud Occurrences}

Professional skepticism is an attitude reflected in a mind that always questions and continuously critically evaluates audit evidence (SPAP, 2013). Professional skepticism is an attitude that an auditor must always hold in carrying out his audit duties. Fullerton and Durtschi (2004) found that the ability to detect fraud owned by auditors will increase when accompanied by high skepticism. This high skepticism will encourage auditors to develop additional information searches when facing symptoms of fraud. This is supported by Julian et al. (2021) and Carpenter and Reimers (2013), who found that if auditors were more skeptical, they would be able to estimate the likelihood of fraud at the audit planning stage, which would lead auditors to improve fraud detection at later audit stages further.

Anggriawan (2014), found that auditors who have a high level of skepticism are able to detect fraud because auditors do not readily believe in the assertions given by management without supporting evidence for these assertions. Furthermore, Noviyanti (2008) found evidence that auditors will only find misstatements caused by errors without applying professional skepticism and will find it challenging to find misstatements caused by fraud. The effect of professional skepticism on the ability of auditors to detect the possibility of fraud can be explained by the AT where 
a person's performance or ability is influenced by internal and external factors (Kiswanto \& Maulana, 2019). Professional skepticism is a factor that comes from within or from the internal auditor. Nasution and Fitriany (2012) found a positive relationship between professional skepticism and the ability of auditors to detect fraud. This is also supported by research by Aminudin and Suryandari (2016); and Butar and Perdana (2017), who stated that professional skepticism positively affects the ability of auditors to detect fraud. Based on the description above, the following hypothesis was developed:

$\mathbf{H}_{1}$ : Professional skepticism has a positive effect on an auditor's ability to detect possible fraud occurrences

\section{Competency and The Auditor's Ability to Detect Possible Fraud Occurrences}

A competent person is a person who, with his skills, does the job efficiently, quickly, intuitively, and rarely makes mistakes. Competency has several components: knowledge, psychological characteristics, thinking skills, decision-making strategies, and task analysis (Baran \& Kłos, 2014). Competence refers to a learning process and increased ability that leads to a better behavior pattern through knowledge, expertise and experience. The auditor's knowledge, expertise, and experience will increase the ability to disclose fraudulent or false financial statements resulting from material misstatements. Based on this, competence will hone one's abilities so that auditors who have knowledge, expertise, and experience are assumed to have better technical expertise in detecting symptoms of fraud.

Tirta and Sholihin (2004) stated that specific task knowledge would affect an auditor's ability to assess the occurrence of fraud. Ardini and Sawarjuwono (2005) stated that auditors need the competence to reveal fraud. Alim et al. (2007) also found evidence that competence has a significant effect on audit quality. In this case, one indication of good audit quality is if the auditor can detect fraud. In this study, it is expected that auditors can use their competence in their duties to detect fraud. Based on this description, the following hypothesis was developed:

$\mathbf{H}_{2}$ : Competence has a positive effect on an auditor's ability to detect possible fraud 


\section{Workload Compression and the Auditor Ability to Detect Possible Fraud Occurrence}

Workload compression is one of the elements that must be considered for a workforce to be in harmony and high work productivity and the additional load elements due to the work environment and work capacity (Sudiharto, 2001). Workload compression that is a too heavy or a physical ability that is too low can decrease the quality of work. Workloads that are too heavy can also cause fatigue, thereby reducing the ability of auditors to spot fraud. Workload compression is defined as how much work a person has to do. According to Novita (2015), auditors find it easier to understand information obtained from clients when faced with a workload that is not too heavy. Research conducted by Nasution and Fitriany (2012) revealed that auditor fatigue during the busy season and tight time budgets for auditors resulted in poor audit quality. Setiawan and Fitriany (2011) stated that low audit quality is due to excessive workloads resulting in suboptimal results. This is reinforced by the results of Novita (2015), which showed that workload compression had a negative effect on the ability of auditors to detect fraud.

The results of previous research indicate that the increase in the workload of auditors will reduce the ability of auditors to detect fraud. Lopez (2005) found that the audit process carried out when there is workload pressure will lower audit quality compared to when there is no workload pressure. Fitriany (2011) conducted a study to see the effect of workload on audit quality and found that workload was proven to have a negative effect on audit quality. From the description above, the following hypothesis was developed:

$\mathbf{H}_{3}$ : Workload compression has a negative effect on an auditor's ability to detect possible fraud.

\section{Moderating Effect of Workload Compression on the Relationship between Internal Factors and the Auditor's Ability to Detect Possible Fraud Occurrences}

The influence of professional skepticism and competence contained in auditors on the ability to detect the possibility of fraud is considered different 
at various levels of external influence (Figueroa \& Cardona, 2013). In the local government environment, the influence of workload is strong, and government auditors will tend to be weak in their efforts to detect possible fraud. This is understandable considering that the overloaded workload will reduce their concentration in carrying out their work. On the other hand, a weak workload will increase their ability to detect fraud. This weak level of workload compression will give auditors plenty of time to examine fraud that may occur during the examination more carefully. This is supported by the fact that someone who is faced with the availability of sufficient completion time will show good performance without worrying about lack of time to complete his work (Figueroa \& Cardona, 2013; Gramling et al., 2013). This is in line with the AT that states that internal and external factors influence a person's performance or ability. The internal factor, in this case, is the professional skepticism and competency of the auditor, while the external factor is the workload of the auditor. Thus, when auditors carry out their audit duties, their success or failure in detecting fraud also depends on the interaction between internal and external factors that exist in the auditor. Based on these arguments, the following hypotheses were developed:

$\mathbf{H}_{4 \mathbf{a}}$ : The positive relationship between professional skepticism and auditor's ability to detect possible fraud will be stronger when workload compression is low.

$\mathbf{H}_{\mathbf{4} \mathbf{b}}$ : The positive relationship between competency and auditor's ability to detect possible fraud will be stronger when workload compression is low.

\section{RESEARCH METHOD}

\section{Type of Data and Data Collection Technique}

This research was quantitatively designed to test the hypotheses using primary data obtained through a questionnaire survey. The population in this study was the Government Internal Supervisory Apparatus at the district/city government in Indonesia. Based on data from the Central Statistics Agency (BPS), the number of districts and cities in Indonesia was 514, consisting of 416 districts and 98 cities (BPS, 2017). The sample for this study was selected using the purposive sampling technique. Purposive sampling is a 
method of determining samples based on specific considerations or criteria (Chandarin, 2018).

The consideration used was that the respondent was an internal auditor who worked for the district/city government with the criteria that the financial statements (LKPD) obtained an unqualified opinion and a qualified opinion from the Supreme Audit Agency. This criterion ensured that the government auditors, as the government's internal auditors, have played a role in carrying out their duties properly. Local governments with unqualified opinions and qualified opinion financial reports indicate that internal audits are running effectively (Siregar, 2015). The results of the examination by the Supreme Audit Agency revealed that 411 LKPD received unqualified opinions and 84 LKPD that obtained qualified opinions (IHPS, 2018). The survey was conducted using a written questionnaire. Questionnaires were delivered directly to respondents and indirectly through intermediaries in the local government.

\section{Operational Definition and Measurement Variable}

The ability to detect the possibility of fraud is an assessment of the capacity of a government auditor on duty in a local government to be able to carry out a process of finding or determining the existence and reality of a shortage of money or misuse of assets as a result of violating the law, whether intentional or not. This ability shows the quality of the auditor's self in explaining the impropriety of a financial report by identifying and proving the presence or absence of potential fraud (Nasution \& Fitriany, 2013). This variable was measured using a Likert scale 1-7 questionnaire. The question items for this construct were adopted and adapted from Fullerton and Durtschi (2004).

Professional skepticism is an auditor's attitude to question and critically evaluate evidence in conducting audit assignments continually. In ISA No. 200, it is said that the attitude of professional skepticism means that the auditor makes a critical assessment, with a questioning mind on the validity and audit evidence obtained, is alert to audit evidence that is contradictory or raises questions regarding the reliability of documents, and respond to questions and other information obtained from management and related parties (Noviyanti, 2008). The professional skepticism variable 
was measured by a questionnaire adopted and adapted from Hurtt's (2010) research with a seven-point Likert scale ranging from 1 (strongly disagree) to 7 (strongly agree).

Competency is knowledge and skills that describe the understanding and proficiency of government auditors in carrying out assigned tasks. The competence of government auditors was measured based on their perception of their recognition of whether they have the knowledge and skills in assessing the possibility of fraud. The question items for this construct were adopted and adapted from previous studies to fit the perspective context in detecting the possibility of fraud. There were eight items for the competency variable based on Bedard and Biggs (2002) with a seven-point Likert scale ranging from 1 (strongly disagree) to 7 (strongly agree).

Workload compression is defined as the quantity and demands of work borne by the government auditor in connection with the audit assignment. The statement on this variable was adapted from Nasution and Fitriany (2012). There were five question items with a seven-point Likert scale used to measure auditor workload variables, ranging from 1 (strongly disagree), to 7 (strongly agree).

\section{Data Analysis Method}

Data was analysed using the Partial Least Squares (PLS) analysis with the help of the SmartPLS V.3.0 application running on computer media. The PLS does not require certain distributed assumptions for parameter estimation so that a parametric technique to test the significance of the parameters is not required (Chin, 1998). PLS testing was carried out in two stages: evaluating the measurement model (outer model) and evaluating the structural model (inner model). Evaluation of the measurement model was used to test the validity and reliability of the construct. While the evaluation of the measurement model was used to evaluate the coefficient of determination $\left(\mathrm{R}^{2}\right)$ and the significance of the construct relationship. 


\section{RESULTS AND DISCUSSION}

From the 300 questionnaires distributed, 164 responses were collected. Fifteen of the returned questionnaires had missing information and were deleted. This is in accordance with Hair et al. (2010), who suggested that respondents who did not answer $10 \%$ of questions measuring latent variables should be excluded from data analysis. Because only a few data was missing $(<10 \%)$, it was replaced by the average response for each affected variable (Pallant, 2011). This measure was considered suitable because surrogate means is a commonly used method in many previous studies as the best single substitute for missing data (Ringle et al., 2010). Accordingly, 149 samples were used for data analysis. The rate of return of the questionnaires was as much as $49.67 \%$.

Because this study was behavioral in nature and adopted a singlerespondent and single-method approach in collecting data for all the variables, a common method bias test was conducted. The test was carried out using Harman's single factor score, in which all items measuring the latent variables were loaded into one common factor. If the results showed that the total variance for one factor was less than $50 \%$, then the data was not affected by the general method bias. Based on the analysis using SPSS, the results showed a total variance of $35.4 \%$ of the total variance. This showed that the data was not affected by the common method bias

\section{Respondents Demographic Characteristics}

As presented in Table 1, out of 149 respondents, 87 respondents were male $(58.39 \%)$, and the remaining 62 respondents were women $(41.61 \%)$. This showed that men were dominant as government auditors who worked at the Regional Inspectorate. The age of respondents under 30 years was as many as 45 people (30.20\%), between 30 and 4054 people (36.9246\%), while respondents who were over 40 years old were 50 people $(33.56 \%)$. 
Table 1: Demographic Profiles of the Respondents

\begin{tabular}{lcc}
\hline & Frequency & Percentage (\%) \\
\hline Sample (N) & 149 & $100.00 \%$ \\
Gender: & & \\
Male & 87 & $58.39 \%$ \\
Female & 62 & $41.61 \%$ \\
Age : & & \\
<30 years & 45 & $30.20 \%$ \\
$30-40$ years & 54 & $36.24 \%$ \\
$>40$ years & 50 & $33.56 \%$ \\
Education: & & \\
Diploma & 42 & $28.19 \%$ \\
Bachelor & 91 & $61.07 \%$ \\
Master & 16 & $10.74 \%$ \\
Phd & 0 & $0.00 \%$ \\
Duration Employed: & & \\
$<10$ years & 84 & $56.38 \%$ \\
$>10$ years & 65 & $43.62 \%$ \\
The Audit Board's Opinion & & \\
Unqualified Opinion & 95 & $63.76 \%$ \\
Qualified Opinion & 54 & $36.24 \%$ \\
Others & 0 & $0.00 \%$ \\
\hline
\end{tabular}

Furthermore, respondents with a diploma education background numbered 42 people (28.19\%), bachelor's degree 91 people (61.07\%), Masters degree 16 people $(10.74 \%)$. Auditors with less than ten years of experience were 84 people $(56.38 \%)$ and more than 65 people had worked for more than ten years $(43.62 \%) .95(63.76 \%)$ of respondents came from local governments who received unqualified opinions, and respondents from local governments who received qualified opinions were as many as 54 people or $36.24 \%$. Opinions referred to in this research are opinions given by the Audit Board of the Financial Statements presented by the Local Government. 


\section{Assessment of The Measurement Model}

By running the algorithm function on the SmartPLS 3.0 software, an illustration of the measurement model was obtained, as shown in Figure 2 below.

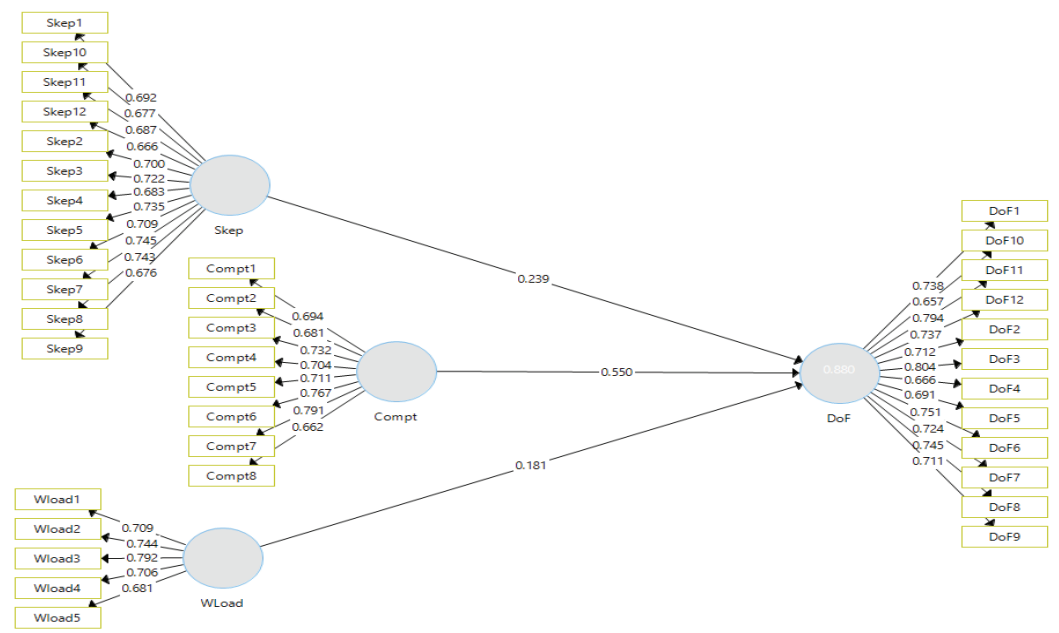

Figure 1: PLS Algorithm of the Measurement Model

\section{Convergent Validity}

Convergent validity test was carried out using model parameters in the form of loading factor values and the Average Variance Extracted (AVE). The rule of thumb for outer loading requires more than 0.70 . However, in this study, the loading factor value above 0.60 was maintained. This refers to Hair et al. (2014), who suggested considering indicators with loadings between 0.40 and 0.70 . Adequate convergent validity is met if the AVE value is at least 0.5 (Hair et al., 2014). As shown in Table 2, the loading factor for all items showed a value above 0.6 , and the four constructs in this study showed an AVE value of above 0.5 . Therefore, the measurements for all the constructs had an acceptable level of convergent validity. 
Asia-Pacific Management Accounting Journal, Volume 16 Issue 3

Table 2: Reflective Measurements and Quality Criteria

\begin{tabular}{|c|c|c|c|}
\hline Reflective and Single- item measure & $\begin{array}{l}\text { Outer Loading } \\
\quad>0.7\end{array}$ & $\begin{array}{c}\text { AVE > } \\
0.50\end{array}$ & $\begin{array}{l}\text { CR > } \\
0.70\end{array}$ \\
\hline Auditor's Ability to detect fraud occurrences & & 0.531 & 0.931 \\
\hline DoF1 & 0.738 & & \\
\hline DoF2 & 0.712 & & \\
\hline DoF3 & 0.804 & & \\
\hline DoF4 & 0.666 & & \\
\hline DoF5 & 0.691 & & \\
\hline DoF6 & 0.751 & & \\
\hline DoF7 & 0.724 & & \\
\hline DoF8 & 0.745 & & \\
\hline DoF9 & 0.711 & & \\
\hline DoF10 & 0.657 & & \\
\hline DoF11 & 0.794 & & \\
\hline DoF12 & 0.737 & & \\
\hline Competency & & 0.517 & 0.895 \\
\hline Compt1 & 0.694 & & \\
\hline Compt2 & 0.681 & & \\
\hline Compt3 & 0.732 & & \\
\hline Compt4 & 0.704 & & \\
\hline Compt5 & 0.711 & & \\
\hline Compt6 & 0.767 & & \\
\hline Compt7 & 0.791 & & \\
\hline Compt8 & 0.662 & & \\
\hline Professional Skepticism & & 0.548 & 0.921 \\
\hline Skep1 & 0.692 & & \\
\hline Skep2 & 0.700 & & \\
\hline Skep3 & 0.722 & & \\
\hline Skep4 & 0.683 & & \\
\hline Skep5 & 0.735 & & \\
\hline Skep6 & 0.709 & & \\
\hline Skep7 & 0.745 & & \\
\hline Skep8 & 0.743 & & \\
\hline
\end{tabular}




\begin{tabular}{lccc}
\hline \multicolumn{1}{c}{ Reflective and Single- item measure } & $\begin{array}{c}\text { Outer Loading } \\
>\mathbf{0 . 7}\end{array}$ & $\begin{array}{c}\text { AVE }>\mathbf{0 . 5 0} \\
\mathbf{0}\end{array}$ & $\begin{array}{c}\text { CR }> \\
\mathbf{0 . 7 0}\end{array}$ \\
\hline Skep9 & 0.676 & & \\
Skep10 & 0.677 & & \\
Skep11 & 0.687 & & \\
Skep12 & 0.666 & & \\
Workload Compression & & 0.848 \\
Wload1 & 0.709 & & \\
Wload2 & 0.744 & & \\
Wload3 & 0.792 & & \\
Wload4 & 0.706 & & \\
Wload5 & 0.681 & & \\
\hline
\end{tabular}

Note: AVE: average variance extracted, CR: composite reliability,

As shown in Figure 1 the loading factor value for all the indicators was above 0.6 . The rule of thumb for the the loading factor is more than 0.70 . However, the loading factor above 0.60 was maintained (Hair et al., 2014). Then as shown in Table 2, it can be concluded that the AVE value for all constructs was above 0.50 . The rule of thumb for the AVE parameter was fulfilled. Therefore all theconstructs were valid. The fulfillment of the outer loadings and AVE parameters indicated that the research model was adequate and met the convergent validity test.

\section{Discriminant validity}

The discriminant validity test was carried out using a heterotraitmonotrait ratio (HTMT) approach from correlation, where if the value of HTMT $<0.90$ then a construct has good discriminant validity (Henseler $\&$ Sarstedt, 2013).

Table 3: Heterotrait-Monotrait Ratio Assessment, CL 95\%

\begin{tabular}{lcccc}
\hline & $\mathbf{1}$ & $\mathbf{2}$ & $\mathbf{3}$ & $\mathbf{4}$ \\
\hline 1. Competency & & & & \\
2. Detection of Fraud Occurrences & 0.638 & & & \\
3. Professional Skepticism & 0.792 & 0.809 & & \\
4. Workload Compression & 0.306 & 0.872 & 0.626 & \\
\hline
\end{tabular}


As shown in Table 3 above, the HTMT value of the correlation between all the constructs was less than 0.9 . Therefore, discriminant validity at the construct level was supported.

\section{Indicator reliability}

The rule of thumb used to assess construct reliability is that the composite reliability value must be greater than 0.7 (Hair, 2015). As shown in Table 2 , the composite reliability values were above 0.70 . Comparatively, Table 4 shows the value of Cronbach's alpha with a value that exceeds the threshold of 0.6 for a reliable model (Nunnally \& Bernstein, 1994). So it can be concluded that the indicators used in this study met the criteria for good reliability.

Table 4: Construct Reliability (Cronbach's Alpha)

\begin{tabular}{llc}
\hline \multicolumn{1}{c}{ Constructs } & Cronbach's Alpha \\
\hline 1. & Detection of Fraud Occurrences & 0.919 \\
2. Professional Skepticism & 0.907 \\
3. Competency & 0.866 \\
4. Workload Compression & 0.776 \\
\hline
\end{tabular}

\section{Assessment of The Structural Model}

\section{Assessment of coefficient of determination $\left(R^{2}\right)$}

Table 5: Coefficient of Determination

\begin{tabular}{cc}
\hline Constructs & $\mathbf{R}^{2}$ \\
\hline Detection of fraud occurrences & 0.879 \\
\hline
\end{tabular}

As shown in Table 5 above, the $\mathrm{R}^{2}$ value obtained for the auditor's ability to detect possible fraud occurrences was 0.879 . The $\mathrm{R}^{2}$ value of 0.879 meant that all constructs together explain the constructs of the ability to detect fraud by $87.9 \%$. While other variables outside the research model explain the remaining $12.1 \%$. $\mathrm{R}^{2}$ values exceeding 0.20 are considered very acceptable in the field of behavioral studies (Hair et al., 2014). 


\section{Assessment of path coefficients}

Figure 2 below shows the results of the bootstrap procedure carried out in Smart PLS, while Table 6 summarizes the path coefficients in the structural model that presents the beta, mean, standard deviation, T-statistic, and $\mathrm{P}$-value values.

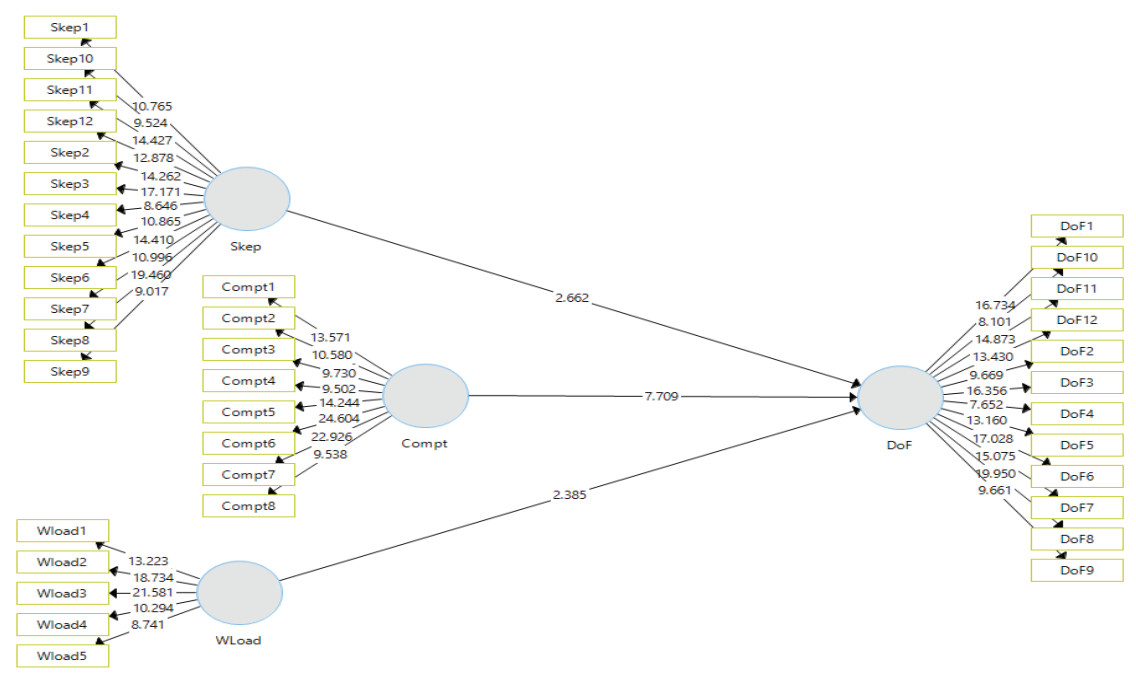

Figure 2: PLS Bootstrapping of the Structural Model

Table 6: Results of Bootstrapping for Assessment of Path Coefficients

\begin{tabular}{ccccccc}
\hline Hypothesis & Path Relationship & $\boldsymbol{\beta}$ & Mean & $\begin{array}{c}\text { Stan. } \\
\text { Dev }\end{array}$ & T-Statistics & $\begin{array}{c}\text { P } \\
\text { Values }\end{array}$ \\
\hline H1 & Skep -> DoF & 0.239 & 0.248 & 0.090 & 2.662 & 0.004 \\
H2 & Compt -> DoF & 0.550 & 0.538 & 0.071 & 7.709 & 0.000 \\
H3 & WLoad -> DoF & 0.181 & 0.185 & 0.076 & 2.385 & 0.009 \\
\hline
\end{tabular}

Based on Table 6 above, it can be concluded that of the three hypotheses developed, two hypotheses were supported, namely, hypothesis H1 (p-value $=0.004)$ and H2 (p-value $=0.000)$. Although H3 hypothesis showed significant results ( $\mathrm{p}$-value $=0.009$ ), it was not supported because it showed a positive relationship direction $(\beta=0.181)$. This was not in accordance with the developed hypothesis. 


\section{Results for moderation effect}

Figure 3 shows the bootstrap of the developed moderation model. The results showed that workload compression was not able to moderate the relationship between internal attributes (professional skepticism and competency) and detection of fraud occurrences. So hypothesis H4a and H4b were not supported. Furthermore, a summary of the results of the moderating effect is tabulated in Table 5. As shown in Table 5 it can be concluded that the moderating effect of workload compression on the relationship between professional skepticism and detection of fraud occurrences showed insignificant results $(\beta=0.088$, pvalue $>0.05)$. Meanwhile, the moderating effect of workload compression on the relationship between competency and detection of fraud occurrences also showed insignificant results $(\beta=$ -0.124 , p-value $>0.074)$.

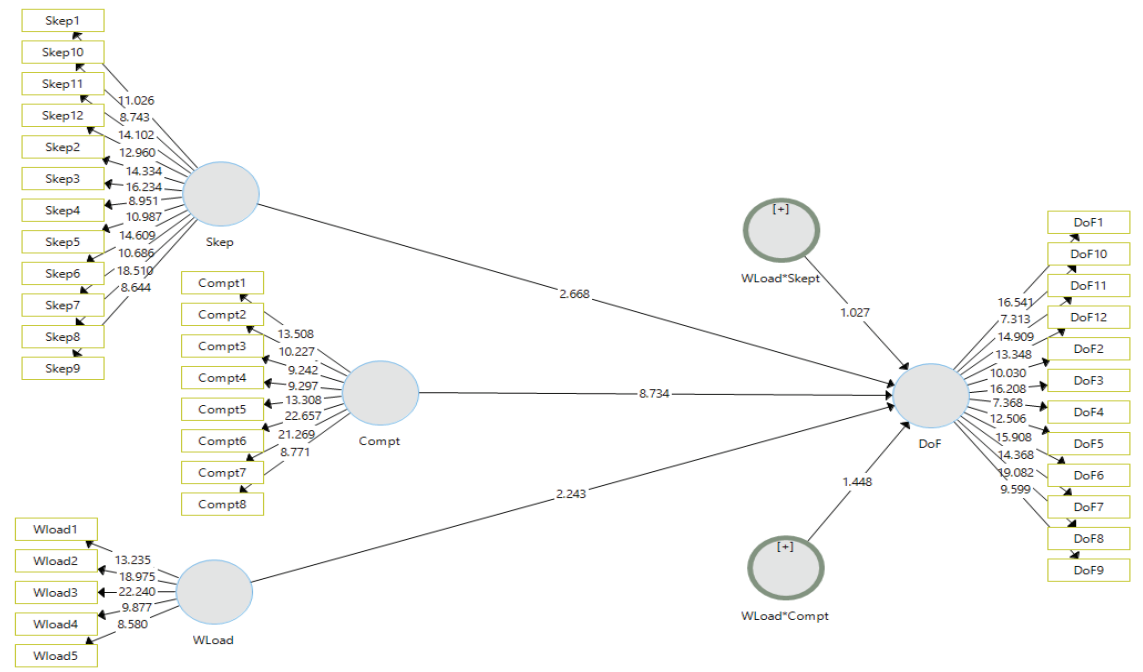

Figure 3: Bootstrapping of the Structural Model for Moderation Effect of Workload Compression 
Table 7: Moderation Effect of Workload Compression

\begin{tabular}{clcccccc}
\hline Hypothesis & \multicolumn{1}{c}{ Path Relationship } & $\boldsymbol{\beta}$ & Mean & $\begin{array}{c}\text { Std. } \\
\text { Dev }\end{array}$ & p-value & \multicolumn{2}{c}{$\begin{array}{c}\text { Confidence } \\
\text { intervals }\end{array}$} \\
\hline \multirow{2}{*}{$\mathrm{H} 4 \mathrm{a} \quad \begin{array}{l}\text { Moderation effect (Workload } \\
\text { compression X professional } \\
\text { skepticism) } \rightarrow \text { Detection of fraud } \\
\text { occurrences }\end{array}$} & 0.088 & 0.085 & 0.086 & 0.152 & -0.048 & 0.230 \\
\hline & $\begin{array}{l}\text { Moderation effect (Workload } \\
\text { compression Xprofessional } \\
\text { skepticism) } \rightarrow \text { Detection of fraud } \\
\text { occurrences }\end{array}$ & -0.124 & -0.119 & 0.086 & 0.074 & -0.267 & 0.014 \\
\hline
\end{tabular}

\section{Discussion of Findings}

The following Table 8, shows a summary of the results of all the hypotheses developed in this study.

Table 8: Summary Results of All Hypothesized Relationship

\begin{tabular}{lll}
\hline \multicolumn{1}{c}{ Hypotheses } & \multicolumn{1}{c}{ Result } \\
\hline $\mathrm{H} 1:$ & $\begin{array}{l}\text { Professional skepticism has a positive effect on the auditor ability } \\
\text { to detect fraud occurrences }\end{array}$ & Supported \\
\hline $\mathrm{H} 2:$ & $\begin{array}{l}\text { Competency has a positive effect on the auditor ability to detect } \\
\text { fraud occurrences }\end{array}$ & Supported \\
\hline $\mathrm{H} 3:$ & $\begin{array}{l}\text { Workload compression has a positive effect on the auditor ability to } \\
\text { detect fraud occurrences }\end{array}$ & Not Supported \\
\hline $\mathrm{H} 4 \mathrm{a}:$ & $\begin{array}{l}\text { The positive relationship between professional skepticism and } \\
\text { auditor's ability to detect possible fraud occurrences will be stronger } \\
\text { when workload compression is lower }\end{array}$ & \\
\hline $\mathrm{H} 4 \mathrm{~b}:$ & $\begin{array}{l}\text { The positive relationship between competency and auditor's ability } \\
\text { to detect possible fraud occurrences will be stronger when workload } \\
\text { compression is lower }\end{array}$ & \\
\hline
\end{tabular}

For hypothesis H1, professional skepticism was found to significantly affect the ability of government auditors to detect possible fraud $(\beta=0.239$, $\mathrm{p}$-value $<0.05$ ). It can be concluded that the ability of government auditors to detect the possibility of fraud is based on the level of skepticism the auditors have. This implies that the ability of government auditors to detect fraud is better when they have high skepticism. The significance of this finding could be due to the contribution of skepticism held by government auditors. These findings suggest that government auditors must equip themselves with skepticism in order to support their performance. In line with the findings in this study, the State Financial Audit Standards (called SPKN), which is 
applied in Indonesia, states that auditors must consider the risk of fraud that can affect audit results.

In addition, the auditor must use professional skepticism in assessing these risks to determine the risks that could affect the audit work if fraud occurs or may have occurred. The findings in this study support the findings of previous studies, including research conducted by Fullerton and Durtschi (2004), Fitriany and Nasution (2012), Rafael (2013), Pramudyastuti (2014), Novianti (2015), and Sofie (2017) which found that professional skepticism had a positive effect on the auditor's ability to detect the possibility of fraud.

The results of the second hypothesis test indicated that competency had a significant positive effect on the ability of auditors to detect the possibility of fraud $(\beta=0.550, p$-value $<0.05)$. This result indicated that the competence possessed by the auditors also determines their ability to detect possible fraud. In addition, these findings indicate that competent auditors will have more knowledge about errors and fraud, which can assist them in assessing audit evidence so that it will improve their performance, including in detecting the possibility of fraud. This finding is in accordance with the results of research by Bonner and Lewis (1990), who found that competence can help better auditor assessments. With good competence, auditors will be able to carry out their duties better in detecting fraud. This study provides additional evidence for previous research that has been carried out including by Tirta and Sholihin (2004), Ardini and Sawarjuwono (2005), and Alim et al. (2007) which found that task-specific knowledge affects auditor performance in detecting the possibility of fraud.

The third hypothesis test, which stated that workload compression has a significant negative effect on the ability of auditors to detect the possibility of fraud, found that this hypothesis was not supported. This indicated that workload did not have a significant effect on the ability of auditors to detect possible fraud ( $\mathrm{p}$-value $>0.05$ ). This finding is probably due to the condition where government auditors already have an annual inspection work program at the beginning of each year so that the workload can be better managed. The annual audit work program allows the lead auditor to distribute the existing workload to auditors from the start by considering the competency and time aspects of the auditors. This result contradicts previous research, including Nasution and Fitriyani (2012); and Molina 
and Safitri (2018), who found that workload had a negative and significant effect on the ability to detect fraud.

The results of the moderation test for hypothesis H4a showed that the moderating effect of workload on the relationship between professional skepticism and the auditor's ability to detect the possibility of fraud was not supported $(\beta=0.088, p$-value $>0.05)$. These results indicated that workload compression was not able to interact with government auditors' skepticism to predict the possibility of fraud. This meant that the relationship of professional skepticism to the government auditor's ability to detect the possibility of fraud was not influenced by the level of workload compression faced by auditors.

Meanwhile, the hypothesis test $\mathrm{H} 4 \mathrm{~b}$, which stated that the positive relationship between competency and auditor's ability to detect possible fraud occurrences will be stronger when workload compression is lower, showed insignificant results $(\beta=-124$, $\mathrm{p}$-value $>0.005)$, so hypothesis $\mathrm{H} 4 \mathrm{~b}$ was not supported. This result is not in line with the findings of Setiawan and Fitriany (2011), which stated that high workloads can cause fatigue which encourages the emergence of dysfunctional audit behavior, resulting in a lack of competence of the auditor in finding errors. In addition, the results of this study were also not in line with the opinion of Schultz (2006), which stated that a higher workload causes employees to experience stress so it affects their ability to carry out their audit tasks.

\section{CONCLUSION}

The results showed that two internal attributes, namely, professional skepticism and competency, had a significant effect on the ability of government auditors to detect the possibility of fraud. Meanwhile, external attributes (workload compression) were found not to significantly affect the ability of government auditors to detect possible fraud. The moderating effect of workload compression was also found to not significantly affect the relationship between internal attributes (professional skepticism and competency) and auditors' ability to detect the possibility of fraud. This means that with workload compression, skeptical and competent government auditors are unable to strengthen or weaken their ability to detect possible 
fraud. These results partially support the AT that internal attributes influence auditors' assessment of the possibility of fraud in the form of professional skepticism and workload compression. However, it failed to prove the influence of external attributes, in this case, workload compression, which in this study was found not to significantly affect auditors' ability to detect the possibility of fraud.

This research can provide some insights for government auditors to improve their ability to detect possible fraud. However, this study still has limitations. This study is based on a quantitative approach that used questionnaires in data collection and this can cause respondents to fail to provide appropriate empirical evidence due to differences in perceptions (Beck et al., 2013). These limitations mean that the results of this study cannot be generalized. Therefore, further research can be extended to a mixed-methods approach, which includes quantitative and qualitative research methods in examining the effect of various factors on fraud detection. This mixed-methods approach will significantly improve the interpretation of research findings (Creswell \& Clark, 2011).

\section{REFERENCES}

Aminudin, M. R., \& Suryandari, D. (2016). Factors affecting auditor's ability in detecting fraud through professional. Accounting Analysis Journal, 5(4), 344-351.

Anggriawan, E. F. (2014). The influence of work experience, professional skepticism, and time pressure on the auditor's ability to detect fraud (Empirical study of public accounting firms in DIY). Nominal Journal, 3(2), 101-116.

Baran, M., \& Kłos, M. (2014). Competency models and the generational diversity of a company workforce. Economics \& Sociology, 7(2), 209-217.

Beasley, M. S., Carcello, J. V., Hermanson, D. R., \& Neal, T. L. (2013). An analysis of alleged auditor deficiencies in SEC fraud investigations: 1998-2010. Center for Audit Quality. Retrieved from http://www. 
thecaq.org/docs/press-release-attachments/caq_ deficienciesmay2013. pdf?sfvrsn=2.

Beck, A. K., Fuller, R. M., Muriel, L., \& Reid, C. D. (2013). Audit fees and investor perceptions of audit characteristics. Behavioral Research in Accounting, 25(2), 71-95.

Bedard, J. C., \& Biggs, S. F. (1991). Pattern recognition, hypotheses generation, and auditor performance in analytical task. The Accounting Review, 66(3), 622-642.

Bedard, J. C., \& Graham, L. E. (2002). The effects of decision aid orientation on risk factor identification and audit test planning. Auditing: A Journal of Practice \& Theory, 21(2), 39-56.

Bonner, S. E., \& Lewis, B. L. (1990). Determinants of auditor expertise. Journal of Accounting Research, 28, 1-20.

Butar, S. G. B., \& Perdana, H. D. (2017). The application of professional skepticism on the government's internal auditors in detecting fraud in the Central Java Province. Journal of Economics and Business, 20(1), 169-189.

Carpenter, T. D., \& Reimers, J. L. (2013). Professional skepticism: The Effects of a partner's influence and the level of fraud indicators on auditors' fraud judgments and actions. Behavioral Research in Accounting, 25(2), 45-69.

Chandarin, G. (2018). Metode riset akuntansi pendekatan kuantitatif(Cetakan $\mathrm{Ke})$. Jakarta: Salemba Empat.

Coram, P., Ferguson, C., \& Moroney, R. (2006). The value of internal audit in fraud detection. Journal of Accounting and Finance, 48(4), 543-559.

Creswell, J. W., \& Clark, V.L.P.(2011). Designing and conducting mixed methods research $\left(2^{\text {nd }}\right.$ ed.). Thousand Oaks, CA: Sage. 
Figueroa, C. R., \& Cardona, R. J. C. (2013, July). Does experience affect auditors' professional judgement? Internal controls and fraud decisions. In Global Conference on Business \& Finance Proceedings (Vol. 8, No. 2, p. 221). Institute for Business \& Finance Research.

Fullerton, R., \& Durtschi, C. (2004). The effect of professional skepticism on the fraud detection skills of internal auditors. Working Paper Series, March 5, 2012.

Gamar, N., \& Djamhuri, A. (2015). Internal auditor as fraud doctor in local government. Multiparadigm Accounting Journal, 6(1), 107-123.

Gramling, A. A., O’Donnell, E. F., \& Vandervelde, S. D. (2013). An experimental examination of factors that influence auditor assessments of a deficiency in internal control over financial reporting. Accounting Horizons, 27(2), 249-269.

Hafizh, Muhammad. (2017). The effect of work experience, accountability, and auditor objetivity on audit quality. Thesis. Padang State University, Padang.

Hartan, T. H., \& Waluyo, I. (2016). The influence of professional skepticism, independence, and competence on the auditor's ability to detect fraud. Profita Journal: Accounting Studies, 4(3), 1-20.

Heider, F. (1958). The psychology of interpersonal relations. New York: Wiley.

Henseler, J., \& Sarstedt, M. (2013). Goodness-of-fit indices for partial least squares path modeling. Computational Statistics, 28(2), 565-580.

Hurtt, R. K. (2010). Development of a scale to measure professional skepticism. Auditing: A Journal of Practice \& Theory, 29(1), 149-171.

Jaffar, N., Salleh, A., Mohd-Iskandar, T., \& Haron, H. (2008). The effect of the external auditors' ability to assess fraud risk on their ability to detect the likelihood of fraud. International Journal of Management Perspectives, 1(1), 49-70. 
Julian, L., Johari, R. J., Said, J. \& Wondabio, L. S. (2021). The effects of tone at the top and professional skepticism on fraud risk judgment among internal auditors in Indonesia. Management and Accounting Review (MAR), 20(1), 139-154.

Kartikarini, N., \& Sugiarto. (2016). The effect of gender, expertise, and professional skepticism on the auditor's ability to detect fraud (Study at the supreme audit agency of the Republic of Indonesia). National Symposium Accounting XIX, Lampung, Gadjah Mada University.

Kiswanto, \& Maulana, P. A. (2019). Experience moderates the fraud risk assessment, skepticism, workload on fraud detection abilities. Scientific Journal of Accounting and Business, 14(2), 183-195.

Lhaksmi, P. O. (2014). The effect of professional skepticism, fraud audit training, and independence on the auditor's ability to detect fraud (Study at the Inspectorate of Sleman regency). Thesis. Gadjah Mada University. Yogyakarta.

Lopez, D. M., \& Peters, G. F. (2012). The effect of workload compression on audit quality. Auditing: A Journal of Practice \& Theory, 31(4), 139-165.

Mala, R., \& Chand, P. (2015). Judgment and decision-making research in auditing and accounting: Future research implications of person, task, and environment perspective. Accounting Perspectives, 14(1), 1-50.

Nasution, H. \& Fitriany. (2012). The influence of workload, audit experience, and personality types on professional skepticism and auditor ability to detect fraud. National Accounting Symposium.

Novita, U. (2015). The effect of experience, workload, and training on skepticism and auditor ability in detecting fraud (Empirical study on auditors at BPKP representatives of Riau province). Jom Fekon, 2(1).

Noviyanti, S. (2008). Auditor's professional skepticism in detecting fraud. Journal of Indonesian Accounting and Finance, 5(1), 102-125.

Pallant, J. (2011). SPSS survival manual: A step by step guide to data analysis using the SPSS program ( $4^{\text {th }}$ ed. $)$. Berkshire: Allen \& Unwin. 
Pradana, S. Y., Tarjo, \& Kompyurini, N. (2013). Detection of fraudulence in public sector organization: Case in Indonesia. The 5th International Conference on Financial Criminology (ICFC).

Ringle, C. M., Sarstedt, M., \& Mooi, E. A. (2010). Response-based segmentation using finite mixture partial least squares. In R. Stahblock, S. F. Crone, \& S. Lessmann (Eds.), Data Mining: Special Issue in Annals of Information Systems. United States, New York: Springer.

Robbins, S. P., \& Judge, T. A. (2008). Organizational behavior book 2, Jakarta: Salemba Empat.

Schultz, D (2006). Psychology work today (9th ed.). New Jersey: Pearson Education, Inc.

Sekaran, U. (2000). Research methods for business. United States of America: John Wiley \& Sons.

Setiawan, L., \& Fitriany. (2011). Effect of workload and auditor specialization on audit quality with audit committee quality as a moderating variable. Journal of Indonesian Accounting and Finance, 8(1).

Simwayi, M., \& Wang, G. (2011). The role of money laundering reporting officers in combating money laundering in Zambia. Journal of Investment Compliance, 12(3), 49-55.

Siregar, R. A. A., \& Setyaningrum, D. (2015). Analisis pengaruh peran badan pengawasan keuangan pemerintah terhadap opini dan temuan audit. September 2015. https://www.researchgate.net/publication/332188361

Suryo, Aji. (2014). Fraud detection in audit (A challenge for auditors). Wahana, 2(I), 53-62.

Tuanakotta, T. M. (2012). Forensic accounting and investigative auditing. Jakarta: Four Salemba. 